\title{
PENGARUH FAKTOR KEMAMPUAN TERHADAP \\ KINERJA UMKM PESERTA PROGRAM PKT DI WILAYAH KEBAYORAN LAMA, JAKARTA SELATAN
}

\author{
Mudjiarto ${ }^{1}$ \\ Apri Yanah Vimesa ${ }^{2}$ \\ ${ }^{1,2}$ Universitas Esa Unggul
}

Email: $\underline{\text { mudjiarto@esaunggul.ac.id }}{ }^{1}, \underline{\text { apriyanahvimesa01@gmail.com }}^{2}$

\begin{abstract}
ABSTRAK
Penelitian ini bertujuan untuk mengetahui pengaruh faktor-faktor kemampuan yang terdiri dari pendidikan, pelatihan, dan pengalaman terhadap kinerja UMKM peserta program Pengembangan Kewirausahaan Terpadu (PKT) di wilayah Kebayoran Lama, Jakarta Selatan. Populasi dalam penelitian ini adalah masyarakat di wilayah Kebayoran Lama yang telah menjalankan UMKM. Dengan jumlah 400 orang, sampel kemudian ditentukan dengan menggunakan metode probability sampling. Hasil analisis regresi linear berganda menunjukkan bahwa pendidikan, pelatihan, dan pengalaman secara parsial berpengaruh positif dan signifikan terhadap kinerja UMKM peserta program PKT di wilayah Kebayoran Lama, Jakarta Selatan.
\end{abstract}

Kata kunci: Faktor kemampuan, pendidikan, pelatihan, pengalaman, kinerja UMKM

\section{ABSTRACT}

This study aims to determine the effect of ability factors consisting of education, training, and experience on the performance of MSME participants in the Integrated Entrepreneurship Development (PKT) program in the Kebayoran Lama area, South Jakarta. The population in this study are people in the Kebayoran Lama area who have run UMKM. With a total of 400 people, the sample was then determined using probability sampling method. The results of multiple linear regression analysis show that education, training, and experience partially have a positive and significant effect on the performance of MSMEs participating in the PKT program in the Kebayoran Lama area, South Jakarta.

Keywords: $\quad$ Ability factors, education, training, experience, performance of MSMEs

\section{PENDAHULUAN}

Perkembangan UMKM di Indonesia mengharuskan para pelaku UMKM untuk bertahan dan bersaing dengan UMKM lainnya. Hal ini memacu para pelaku UMKM untuk menciptakan usaha-usaha yang baru dan berbeda yang diiringi dengan kinerja yang baik. Kinerja itu sendiri merupakan hasil pekerjaan yang menjadi ukuran keberhasilan bagi sebuah entitas usaha dalam mencapai tujuannya. Kinerja berkaitan dengan melakukan pekerjaan, hasil yang dicapai dari pekerjaaan tersebut, apa yang dikerjakan, serta bagaimana cara mengerjakannya.

Kinerja yang kurang baik dapat dipengaruhi oleh berbagai faktor internal maupun 
eksternal. Munizu (2010) menyebutkan bahwa faktor-faktor yang mempengaruhi kinerja UMKM antara lain mencakup aspek SDM, aspek keuangan, aspek teknis produksi dan operasi, aspek pasar, aspek kebijakan pemerintah, aspek sosial, budaya dan ekonomi, serta aspek peranan lembaga terkait. Hal ini juga didukung oleh penelitian yang dilakukan oleh Safik dan Suparwati (2013) menyebutkan aspek SDM sebagai faktor yang signifikan dalam mempengaruhi kinerja UKM. Selain itu, Tambunan (2004) juga berpendapat bahwa keterbatasan SDM yang diiringi dengan keterbatasan modal dan teknologi merupakan salah satu penyebab utama rendahnya daya saing produk UMKM dari produk-produk industri besar.

Kompetensi SDM merupakan salah satu faktor yang mempengaruhi kinerja UMKM. Faktor SDM menjadi modal utama untuk membuat UMKM menjadi lebih profesional. Hal ini dikarenakan sebuah unit bisnis ditentukan oleh bagaimana individuindividu yang terlibat di dalam mengelola bisnis tersebut. Kinerja UMKM harus disertai dengan pengembangan usahanya, namun pengembangan UMKM itu sendiri juga harus disertai dengan pengembangan SDM dalam berbagai aspek. Kualitas SDM diperlukan terutama di bidang kompetensi SDM, seperti pengetahuan (knowledge), keterampilan (skill), dan kemampuan (ability) dalam berwirausaha (Ardiana dkk., 2010).

Faktor pendidikan dan pelatihan merupakan salah satu faktor dalam pengembangan SDM, terutama untuk mengembangkan kemampuan intelektual dan kepribadian manusia (Notoatmodjo, 2009). Kedua faktor tersebut ditujukan agar SDM dapat meningkatkan kompetensinya. Berdasarkan hasil pra-survei, dapat dilihat bahwa tingkat pendidikan terakhir yang ditempuh oleh para pelaku UMKM di Kebayoran Lama, Jakarta Selatan di antaranya $8 \%$ di tingkat SD, $19 \%$ di tingkat SMP, 52\% di tingkat SMA, $8 \%$ di tingkat D3/Diploma, dan $11 \%$ di tingkat S1/Sarjana. Hal tersebut menunjukkan masih relatif rendahnya tingkat pendidikan terakhir dari para pelaku UMKM di Kebayoran Lama.

Pelatihan merupakan tanggung jawab pengelola usaha untuk mengembangkan kinerja SDM-nya dalam rangka meningkatkan daya saing. Bagi UMKM, pemerintah memberikan dukungan yang cukup kuat dengan mengadakan pelatihan berkala untuk menunjang fundamental dan menambah pengetahuan para pelaku UMKM berkaitan dengan bisnis yang dijalankannya. Berdasarkan hasil pra-survei terhadap para pelaku UMKM yang telah mengkuti pelatihan FGD pada program Pengembangan Kewirausahaan Terpadu (PKT) di wilayah Jakarta Selatan, besarnya persentase pelaku UMKM yang mengikuti pelatihan OK-OC adalah 19\%, pelatihan make-up / menjahit 10\%, tata boga 
$12 \%$, mengetik $1 \%$, sosialisasi penyuluhan $1 \%$, komputer / bahasa Inggris $9 \%$, dan besarnya persentase yang tidak mengikuti pelatihan adalah $48 \%$.

Selain faktor pendidikan dan pelatihan, faktor pengalaman juga sangat mempengaruhi kinerja SDM karena semakin lama pengalaman kerja yang dimiliki oleh seseorang, maka umumnya akan semakin baik pula tingkat keahlian yang dimiliki oleh orang tersebut di bidangnya. Pengalaman kerja itu sendiri merupakan proses atau tingkat penguasaan pengetahuan serta keterampilan seseorang dalam pekerjaanya yang dapat diukur dari masa kerja, tingkat pengetahuan, dan keterampilan yang dimilikinya. Orang yang berpengalaman dalam bekerja cenderung memiliki kemampuan kerja yang lebih baik dari orang yang baru saja memasuki dunia kerja karena orang tersebut telah belajar dari berbagai kegiatan dan permasalahan yang timbul berdasarkan pengalaman kerjanya. Dengan adanya pengalaman kerja, maka telah terjadi proses penambahan ilmu pengetahuan dan keterampilan serta sikap pada diri seseorang yang dapat menunjang dalam pengembangan diri dengan perubahan yang ada. Dengan pengalaman yang didapat, seseorang cenderung akan lebih cakap dan terampil serta mampu melaksanakan tugas pekerjaannya.

Meskipun perkembangan UMKM di Indonesia berjalan dengan cukup pesat selama beberapa tahun terakhir, akan tetapi berdasarkan hasil pra-survei yang dilakukan, UMKM di Indonesia umumnya masih kurang memperhatikan kemampuan SDM-nya yang antara lain mencakup faktor pendidikan, pelatihan, dan pengalaman. Hal inilah yang dinilai masih menghambat kinerja dan daya saing UMKM. Oleh karena itu, perlu dilakukan penelitian untuk menganalisis pengaruh faktor-faktor kemampuan yang terdiri dari pendidikan, pelatihan, dan pengalaman terhadap kinerja UMKM agar ketiga faktor kemampuan tersebut nantinya dapat dioptimalisasikan untuk meningkatkan kinerja UMKM. Dalam hal ini, kinerja UMKM yang dianalisis akan direpresentasikan oleh UMKM peserta program PKT di wilayah Kebayoran Lama, Jakarta Selatan.

\section{TINJAUAN PUSTAKA}

\section{Usaha Mikro Kecil Menengah (UMKM)}

UMKM adalah unit usaha produktif yang berdiri sendiri dan dilakukan oleh orang perorangan ataupun badan usaha di semua sektor ekonomi (Tambunan, 2012). Pada prinsipnya, pembedaan antara Usaha Mikro (UMi), Usaha Kecil (UK), Usaha Menengah (UM), dan Usaha Besar (UB) umumnya didasarkan pada nilai aset awal (tidak termasuk 
tanah dan bangunan), omzet rata-rata per tahun, atau jumlah pekerja tetap. Akan tetapi, definisi UMKM berdasarkan ketiga alat ukur ini berbeda di setiap negara.

\section{Pendidikan}

Berdasarkan UU No. 2 Tahun 1989 tentang Sistem Pendidikan Nasional, pendidikan adalah suatu usaha untuk menyiapkan peserta didik melalui kegiatan bimbingan, pengajaran, dan latihan bagi peranannya di masa yang akan datang. Dengan memperhatikan pengertian pendidikan tersebut, maka dapat dikatakan bahwa peran pendidikan adalah sebagai landasan untuk membentuk, mempersiapkan, membina, dan mengembangkan kemampuan sumber daya manusia yang sangat menentukan dalam keberhasilan pembangunan di masa yang akan datang. Menurut Beby (1996), pendidikan dapat dikatakan mempunyai kualitas yang tinggi apabila keluaran dari pendidikan itu sendiri mempunyai nilai bagi masyarakat yang memerlukan pendidikan tersebut.

\section{Pelatihan}

Menurut UU No. 21 Tahun 2000 tentang Serikat Pekerja / Serikat Buruh, pelatihan kerja adalah keseluruhan kegiatan untuk memberi, memperoleh, meningkatkan, serta mengembangkan kompetensi kerja, produktivitas, disiplin, sikap, dan etos kerja pada tingkat keterampilan dan keahlian tertentu sesuai dengan jenjang kualifikasi jabatan atau pekerjaan. Adapun Mathis dan Jackson (2011) mendefinisikan pelatihan sebagai sebuah proses dimana orang mendapatkan kapabilitas untuk membantu untuk melakukan pekerjaan. Widodo (2015) mengungkapkan bahwa pelatihan cenderung lebih berorientasi pada pekerjaan saat ini untuk meningkatkan keterampilan-keterampilan tertentu.

\section{Pengalaman}

Pengalaman dapat didefinisikan sebagai suatu ukuran tentang lama waktu atau masa kerja yang telah ditempuh seseorang dalam memahami tugas-tugas suatu pekerjaan dan telah melaksanakannya dengan baik (Foster dan Karen, 2001). Dengan demikian, dapat dipahami bahwa pengalaman kerja menunjukkan berapa lama yang diperlukan oleh seorang individu atau pegawai untuk dapat bekerja dengan baik. Pengalaman kerja juga meliputi banyaknya jenis pekerjaan atau jabatan yang pernah diduduki oleh seseorang dan lamanya mereka bekerja pada masing-masing pekerjaan atau jabatan tertentu (Siagian, 1999). 


\section{Kinerja}

Menurut Ranto (2007), kinerja merupakan serangkaian kegiatan manajemen yang memberikan gambaran mengenai sejauh mana hasil yang sudah dicapai dalam melaksanakan tugas dan tanggung jawabnya dalan akuntabilitas publik baik berupa keberhasilan maupun kekurangan yang terjadi. Kinerja merupakan hasil dari suatu proses atau tingkat keberhasilan seseorang selama periode tertentu dalam melaksanakan tugasnya, baik secara kualitas maupun kuantitas (Mangkunegara, 2001).

Sebagian besar perusahaan mengukur kinerjanya berdasarkan tingkat penjualan dan laba perusahaan dalam kurun waktu tertentu. Selain itu, kinerja sering diukur dengan membandingkan antara kinerja aktual daan kinerja yang direncanakan. Penilaian kinerja suatu organisasi sendiri sering diartikan dengan kata assesment, dimana kinerja perusahaan itu sendiri merupakan sesuatu yang dihasilkan oleh suatu perusahaan dalam periode tertentu dengan mengacu pada standar yang ditetapkan. Penilaian kinerja merupakan penilaian secara periodik mengenai efektivitas operasional suatu organisasi, bagian organisasi, dan karyawan berdasarkan sasaran, standar, dan kriteria yang telah ditetapkan sebelumnya.

\section{Hipotesis Penelitian}

Hipotesis penelitian ini dirumuskan sebagai berikut.

$\mathrm{H}_{1}$ : Pendidikan berpengaruh positif dan signifikan terhadap kinerja UMKM peserta program PKT di wilayah Kebayoran Lama, Jakarta Selatan.

$\mathrm{H}_{2}$ : Pelatihan berpengaruh positif dan signifikan terhadap kinerja UMKM peserta program PKT di wilayah Kebayoran Lama, Jakarta Selatan.

$\mathrm{H}_{1}$ : Pengalaman berpengaruh positif dan signifikan terhadap kinerja UMKM peserta program PKT di wilayah Kebayoran Lama, Jakarta Selatan.

\section{Kerangka Pemikiran}

Kerangka pemikiran yang digunakan dalam penelitian ini dapat dilihat sebagai berikut. 


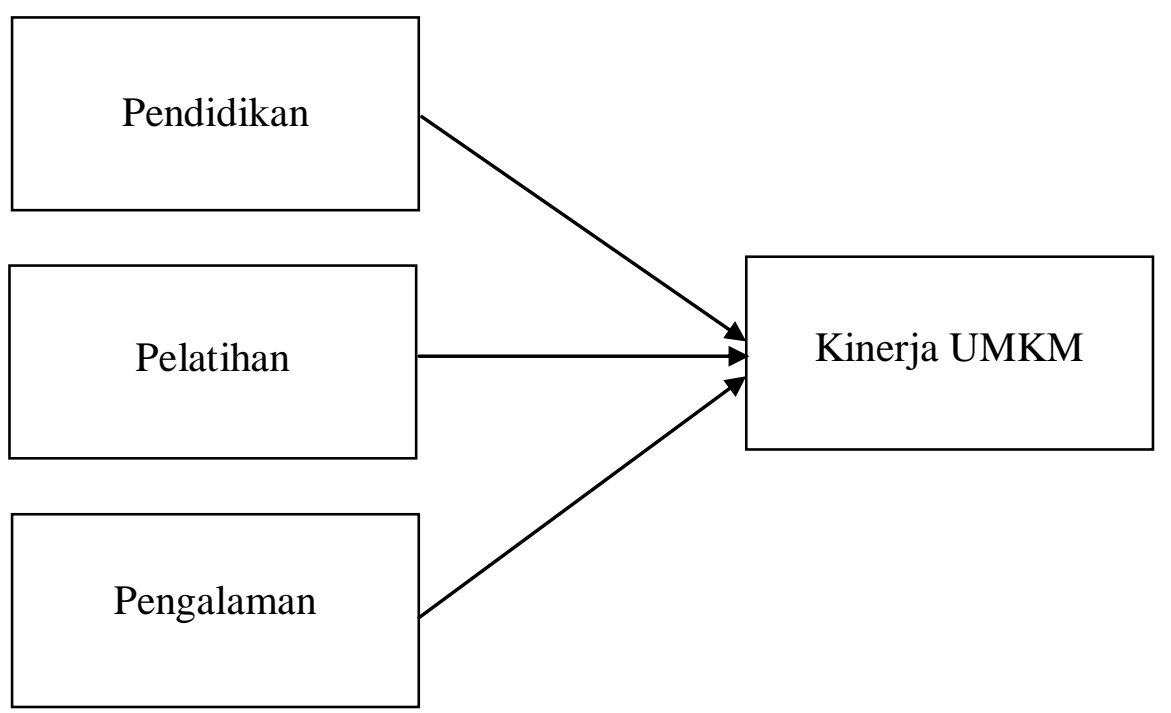

Gambar 1. Kerangka Pemikiran

\section{METODOLOGI PENELITIAN}

\section{Jenis dan Sumber Data}

Data yang digunakan dalam penelitian ini adalah data cross section yang diperoleh dari sumber primer, yakni dari hasil penyebaran kuesioner kepada responden penelitian.

\section{Populasi dan Sampel}

Populasi dalam penelitian ini adalah masyarakat di wilayah Kebayoran Lama, Jakarta Selatan yang telah menjalankan UMKM. Dari 400 orang jumlah populasi tersebut, jumlah sampel ditentukan sebanyak 80 responden berdasarkan rumus Slovin. Pengambilan sampel tersebut dilakukan dengan menggunakan metode probability sampling yang memberikan peluang yang sama bagi setiap unsur (anggota) populasi untuk dipilih menjadi anggota sampel.

\section{Metode Analisis}

Penelitian ini menggunakan metode analisis regresi linear berganda untuk menganalisis pengaruh pendidikan, pelatihan, dan pengalaman terhadap kinerja UMKM peserta program PKT di wilayah Kebayoran Lama, Jakarta Selatan. Sebelum dianalisis, instrumen penelitian telah terlebih dahulu diuji validitas dan reliabilitasnya. 


\section{HASIL DAN PEMBAHASAN}

\section{Hasil Uji Instrumen}

Berdasarkan hasil uji validitas, seluruh pernyataan dinilai valid karena memiliki

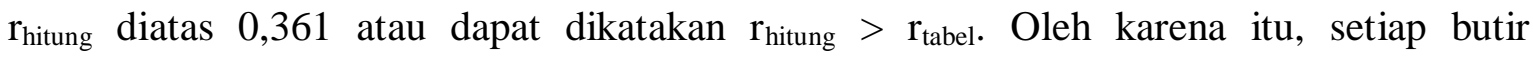
pernyataan terbukti layak untuk digunakan dalam pengukuran indikator dan variabel penelitian. Adapun uji reliabilitas menghasilkan nilai cronbach alpha sebesar 0,713 yang melebihi batas minimal 0,60, sehingga bahwa seluruh pernyataan dalam penelitian dinyatakan reliabel.

\section{Hasil Uji Regresi Linear Berganda}

Berdasarkan uji regresi linear berganda, diperoleh hasil yang dapat dilihat pada tabel berikut ini.

Tabel 1. Hasil Uji Regresi Linear Berganda

\begin{tabular}{|l|c|c|c|c|c|}
\hline \multirow{2}{*}{ Model } & \multicolumn{2}{|c|}{$\begin{array}{c}\text { Unstandardized } \\
\text { Coefficienents }\end{array}$} & $\begin{array}{c}\text { Standardized } \\
\text { Coefficients }\end{array}$ & \multirow{2}{*}{$\mathbf{t}$} & \multirow{2}{*}{ Sig. } \\
\cline { 2 - 5 } & $\mathbf{B}$ & $\begin{array}{c}\text { Std. } \\
\text { Error }\end{array}$ & Beta & & \\
\hline (Constant) & 8,234 & 3,231 & & 2,548 & 0,013 \\
\hline Pendidikan & 0,327 & 0,106 & 0,311 & 3,079 & 0,003 \\
\hline Pelatihan & 0,221 & 0,077 & 0,282 & 2,883 & 0,005 \\
\hline Pengalaman & 0,278 & 0,102 & 0,277 & 2,728 & 0,008 \\
\hline
\end{tabular}

(Sumber: Data diolah)

Berdasarkan tabel di atas, dapat disusun persamaan regresi linear berganda sebagai berikut.

$$
Y=8,234+0,327 X_{1}+0,221 X_{2}+0,278 X_{3}
$$

Keterangan:

$$
\begin{array}{ll}
\mathrm{Y} & =\text { Kinerja UMKM } \\
x_{1} & =\text { Pendidikan } \\
X_{2} & =\text { Pelatihan } \\
X_{3} & =\text { Pengalaman }
\end{array}
$$

Persamaan di atas dapat diinterpretasikan sebagai berikut.

1. Nilai konstanta sebesar 8,234 menunjukkan bahwa jika variabel pendidikan, pelatihan, dan pengalaman dianggap konstan, maka variabel kinerja bernilai 8,234.

2. Koefisien regresi variabel pendidikan sebesar 0,327 menunjukkan bahwa jika 
variabel pendidikan mengalami kenaikan sebesar satu satuan skala likert, maka kinerja UMKM peserta program PKT di wilayah Kebayoran Lama, Jakarta Selatan akan mengalami kenaikan sebesar 0,327 dengan asumsi ceteris paribus.

3. Koefisien regresi variabel pelatihan sebesar 0,221 menunjukkan bahwa jika variabel pelatihan mengalami kenaikan sebesar satu satuan skala likert, maka kinerja UMKM peserta program PKT di wilayah Kebayoran Lama, Jakarta Selatan akan mengalami kenaikan sebesar 0,221 dengan asumsi ceteris paribus.

4. Koefisien regresi variabel pengalaman sebesar 0,278 menunjukkan bahwa jika variabel pengalaman mengalami kenaikan sebesar satu satuan skala likert, maka kinerja UMKM peserta program PKT di wilayah Kebayoran Lama, Jakarta Selatan akan mengalami kenaikan sebesar 0,278 dengan asumsi ceteris paribus.

\section{Hasil Uji Kelayakan Model}

Hasil uji kelayakan model dengan menggunakan uji $\mathrm{F}$ dapat dilihat pada tabel sebagai berikut.

Tabel 2. Hasil Uji F

\begin{tabular}{|l|r|r|r|r|c|}
\hline \multicolumn{1}{|c|}{ Model } & $\begin{array}{c}\text { Sum of } \\
\text { Squares }\end{array}$ & df & $\begin{array}{c}\text { Mean } \\
\text { Square }\end{array}$ & F & Sig. \\
\hline Regression & 66,329 & 3 & 22,110 & 10,330 & $0,000^{\mathrm{b}}$ \\
\hline Residual & 162,671 & 76 & 2,140 & & \\
\hline Total & 229,000 & 79 & & & \\
\hline
\end{tabular}

(Sumber: Data diolah)

Berdasarkan tabel di atas, diperoleh $\mathrm{F}_{\text {hitung }}$ sebesar 10,330 dengan tingkat signifikan 0,000 yang lebih kecil daripada 0,05 , sehingga $\mathrm{H}_{0}$ ditolak dan $\mathrm{H}_{\mathrm{a}}$ diterima. Artinya, pendidikan, pelatihan, dan pengalaman secara simultan berpengaruh siginifikan terhadap kinerja UMKM peserta program PKT di wilayah Kebayoran Lama, Jakarta Selatan.

\section{Hasil Uji Hipotesis}

Hasil uji hipotesis dengan menggunakan uji t dapat dilihat pada tabel berikut ini.

Tabel 3. Hasil Uji Hipotesis

\begin{tabular}{|l|c|c|}
\hline \multicolumn{1}{|c|}{ Model } & T & Sig. \\
\hline Pendidikan & 3,079 & 0,003 \\
\hline Pelatihan & 2,883 & 0,005 \\
\hline Pengalaman & 2,728 & 0,008 \\
\hline Sumber: Data diolah)
\end{tabular}


Hasil uji t di atas dapat diinterpretasikan sebagai berikut.

1. Variabel pendidikan memiliki nilai $t_{\text {hitung }}$ sebesar 3,079 dan nilai signifikan sebesar 0,003 yang lebih kecil daripada 0,05 , sehingga $\mathrm{H}_{0}$ ditolak dan $\mathrm{H}_{\mathrm{a}}$ diterima. Hal tersebut menunjukkan bahwa pendidikan berpengaruh positif dan signifikan terhadap kinerja UMKM peserta program PKT di wilayah Kebayoran Lama, Jakarta Selatan.

2. Variabel pelatihan memiliki nilai $t_{\text {hitung }}$ sebesar 2,883 dan nilai signifikan sebesar 0,005 yang lebih kecil daripada 0,05 , sehingga $\mathrm{H}_{0}$ ditolak dan $\mathrm{H}_{\mathrm{a}}$ diterima. Hal tersebut menunjukkan bahwa pelatihan berpengaruh positif dan signifikan terhadap kinerja UMKM peserta program PKT di wilayah Kebayoran Lama, Jakarta Selatan.

3. Variabel pengalaman memiliki nilai $t_{\text {hitung }}$ sebesar 2,728 dan nilai signifikan sebesar 0,008 yang lebih kecil daripada 0,05 , sehingga $\mathrm{H}_{0}$ ditolak dan $\mathrm{H}_{\mathrm{a}}$ diterima. Hal tersebut menunjukkan bahwa pengalaman berpengaruh positif dan signifikan terhadap kinerja UMKM peserta program PKT di wilayah Kebayoran Lama, Jakarta Selatan.

\section{Pembahasan}

\section{Pengaruh Pendidikan terhadap Kinerja UMKM}

Hasil penelitian ini menunjukkan bahwa pendidikan berpengaruh positif dan signifikan terhadap kinerja UMKM, sehingga semakin baik tingkat pendidikan yang ditempuh oleh pelaku UMKM, maka semakin tinggi kinerja dari UMKM yang dikelolanya. Hal ini terjadi karena pendidikan itu sendiri merupakan suatu kegiatan yang ditujukan untuk meningkatkan penguasaan teori dan keterampilan memutuskan terhadap persoalan-persoalan yang menyangkut kegiatan pencapaian tujuan. Pelaku UMKM yang memiliki pendidikan yang baik cenderung memiliki pengetahuan yang cukup untuk membantunya memahami usaha yang dijalankannya dan memiliki pola pikir yang mendukung untuk menjalankan usahanya tersebut, sehingga usaha dapat dijalankan secara optimal. Selain itu, pengetahuan yang diperoleh dari suatu proses pendidikan juga dapat membantu pelaku UMKM dalam menemukan solusi dari berbagai permasalahan yang dihadapinya selama menjalankan usahanya. 


\section{Pengaruh Pelatihan terhadap Kinerja UMKM}

Hasil penelitian ini menunjukkan bahwa pelatihan berpengaruh positif dan signifikan terhadap kinerja UMKM, sehingga semakin baik tingkat pelatihan yang diikuti oleh pelaku UMKM, maka semakin tinggi kinerja dari UMKM yang dikelolanya. Hal ini terjadi karena pelatihan itu sendiri merupakan upaya yang direncanakan untuk mempermudah pembelajaran tentang pengetahuan, keterampilan, dan perilaku yang berkaitan dengan pekerjaan. Sasaran pelatihan adalah menguasai pengetahuan, keterampilan, dan perilaku yang ditekankan pada program-program pelatihan serta menerapkannya ke dalam berbagai aktivitas sehari-hari. Oleh karena itu, pelaku UMKM yang menerima pelatihan cenderung akan mampu meningkatkan pengetahuan dan kemampuannya sehingga membuatnya dapat melaksanakan pekerjaannya secara lebih baik, efektif, dan efisien. Pelaku UMKM yang menerima pelatihan akan lebih memahami bidang yang dijalankannya, sehingga dapat menjalankan usahanya secara lebih optimal. Selain itu, pelatihan juga dapat meningkatkan rasa percaya diri pelaku UMKM dalam menghadapi sistem yang baru.

\section{Pengaruh Pengalaman terhadap Kinerja UMKM}

Hasil penelitian ini menunjukkan bahwa pengalaman berpengaruh positif dan signifikan terhadap kinerja UMKM, sehingga semakin baik tingkat pengalaman yang dimiliki oleh pelaku UMKM, maka semakin tinggi kinerja dari UMKM yang dikelolanya. Hal ini terjadi karena pengalaman pelaku UMKM akan sangat mempengaruhinya dalam menguasai keahlian di bidang usaha yang dijalaninya mengingat pengalaman kerja itu sendiri merupakan suatu proses atau tingkat penguasaan pengetahuan serta keterampilan seseorang dalam pekerjaanya yang dapat diukur dari masa kerja, tingkat pengetahuan, dan keterampilan yang dimilikinya.

\section{KESIMPULAN DAN SARAN}

\section{Kesimpulan}

Kesimpulan yang dapat ditarik dari penelitian ini antara lain sebagai berikut.

1. Pendidikan berpengaruh positif dan signifikan terhadap kinerja UMKM peserta program PKT di wilayah Kebayoran Lama, Jakarta Selatan.

2. Pelatihan berpengaruh positif dan signifikan terhadap kinerja UMKM peserta program PKT di wilayah Kebayoran Lama, Jakarta Selatan. 
3. Pengalaman berpengaruh positif dan signifikan terhadap kinerja UMKM peserta program PKT di wilayah Kebayoran Lama, Jakarta Selatan.

\section{Saran}

Berdasarkan kesimpulan di atas, berikut ini saran yang dapat diberikan.

1. Para pelaku UMKM diharapkan dapat meningkatkan pendidikan, pelatihan, dan pengalamannya di bidang yang relevan agar kinerja UMKM yang dikelolanya juga dapat mengalami peningkatan.

2. Para peneliti selanjutnya diharapkan dapat menambah variabel lain yang dapat mempengaruhi kinerja UMKM selain pendidikan, pelatihan, dan pengalaman agar mempu lebih memahami variabel-variabel yang mempengaruhi kinerja UMKM.

3. Para peneliti selanjutnya diharapkan dapat menggunakan sampel yang lebih banyak dan menggunakan alat analisis yang berbeda sebagai perbandingan dan referensi lebih lanjut.

\section{DAFTAR PUSTAKA}

Ardiana, I.D.K.R., I.A. Brahmayanti, dan Subaedi. 2010. Kompetensi SDM UKM dan Pengaruhnya terhadap Kinerja UKM di Surabaya. Jurnal Manajemen dan Kewirausahaan. 12(1): 42-55.

Astuti, W. dan Murwatiningsih. 2016. Pengaruh Kemampuan Manajemen dan Karakteristik Usaha terhadap Kinerja Usaha UKM Olahan Produk Salak di Kabupaten Banjarnegara. Management Analysis Journal. 5(2): 123-127.

Foster, B.S. dan R. Karen. 2001. Pembinaan untuk Meningkatkan Kinerja Karyawan. PPM. Jakarta.

Hendriani, S., Y. Efni, dan A. Fitriani. 2013. Pengaruh Pendidikan dan Pelatihan, Kompetensi terhadap Kinerja Karyawan. Pekbis Jurnal. 5(2): 133-144.

Herlina, E. 2014. Pendidikan dan Pelatihan dalam Meningkatkan Model Kerjasama Usaha Menengah Kecil dan Mikro dengan Usaha Besar di Kecamatan Cikoneng Kabupaten Ciamis. Ekonologi: Jurnal Ilmu Manajemen Universitas Galuh Ciamis. 1(1): 71-81.

Mangkunegara, A.P. 2001. Manajemen Sumber Daya Manusia Perusahaan. Remaja Rosdakarya. Bandung.

Mathis, R.L. dan J.H. Jackson. 2002. Human Resource Management. $10^{\text {th }}$ Edition. SouthWestern. Mason. Terjemahan J. Sadeli dan B.P. Hie. 2011. Manajemen Sumber Daya Manusia. Edisi 10. Salemba Empat. Jakarta. 
Mudjiarto. 2014. Pengaruh Pembinaan Manajemen Usaha terhadap Kinerja Usaha Mitra Binaan PKBL PT Jasa Marga. Jurnal Ekonomi. 5(2): 80-87.

, A. Wahid, dan A. Sugiharto. 2016. Faktor-Faktor yang Mempengaruhi Kinerja Usaha Kecil Menengah Mitra Binaan PKBL PT Jasa Marga. Jurnal Ekonomi. 7(2): 164-171.

2019. Model Pembinaan UMKM Program Kementerian Badan Usaha Milik Negara: Kasus Mitra Binaan UMKM Wilayah Jakarta, Bogor. Ikraith Ekonomika. 2(2): 105-112.

Munizu, M. 2010. Pengaruh Faktor-Faktor Eksternal dan Internal terhadap Kinerja Usaha Mikro dan Kecil di Sulawesi Selatan. Jurnal Manajemen dan Kewirausahaan. 12(1): 33-41.

Notoatmodjo, S. 2009. Pengembangan Sumber Daya Manusia. Rineka Cipta. Jakarta.

Ranto, B. 2007. Analisis Hubungan antara Motivasi, Pengetahuan Kewirausahaan, dan Kemandirian Usaha terhadap Kinerja Pengusaha pada Kawasan Industri Kecil di Daerah Pulogadung. Jurnal Usahawan. 36(10).

Safik, A. dan Y.K. Suparwati. 2013. Pengaruh Kompetensi SDM, Kualitas Informasi Keuangan dan Locus of Control terhadap Kinerja UMKM: Studi pada UMKM Binaan Dinas Koperasi di Kec. Kertek Kab. Wonosobo. PRESTASI. 11(1).

Siagian, S.P. 1999. Manajemen Sumber Daya Manusia. Bumi Aksara. Jakarta.

Tambunan, T. 2004. Globalisasi dan Perdagangan Internasional. Ghalia Indonesia. Jakarta.

2004. Pertumbuhan Ekonomi dan Pembangunan Kemiskinan: Kasus Indonesia. Kajian Ekonomi Jurnal Penelitian Bidang Ekonomi. 3(2).

2013. UMKM Indonesia. Ghalia Indonesia. Bogor.

Tri, D.D. dan Darwanto. 2013. Pengembangan Usaha Mikro Kecil dan Menengah (UMKM) Berbasis Ekonomi Kreatif di Kota Semarang. Diponegoro Journal of Economics. 2(4): 1-13.

Undang-Undang Republik Indonesia Nomor 2 Tahun 1989. Sistem Pendidikan Nasional. 27 Maret 1989. Lembaran Negara Republik Indonesia Tahun 1989 Nomor 6. Jakarta.

Undang-Undang Republik Indonesia Nomor 21 Tahun 2000. Serikat Pekerja / Serikat Buruh. 4 Agustus 2000. Lembaran Negara Republik Indonesia Tahun 2000 Nomor 131. Jakarta.

Widodo. 2015. Manajemen Pengembangan Sumber Daya Manusia. Pustaka Pelajar. Yogyakarta. 